\title{
A Single Chip Standalone Water Splitting Photoelectrochemical Cell
}

\author{
Mourad Frites ${ }^{1}$, William B. Ingler Jr. ${ }^{2}$ and Shahed U.M. Khan ${ }^{1, *}$ \\ ${ }^{1}$ Department of Chemistry and Biochemistry, Duquesne University, Pittsburgh, PA 15282, USA \\ ${ }^{2}$ Sunnyfuel LLP, 200 West Scott Park Drive, Toledo, OH 43607, USA
}

\begin{abstract}
Water splitting photoelectrochemical cell (PEC) was fabricated in which the electrolyzer parts were made on a single chip. This was achieved by depositing an optically transparent $\mathrm{Mn}$-oxide- $\mathrm{TiO}_{2}$ thin layer on the front of a triple junction amorphous Si photovoltaic cell which acted as the anode and the back stainless steel layer acted as the cathode under illumination of light. This single chip water electrolysis cell operates like an artificial leaf. Water splitting was observed by simply submersing the device in a basic electrolyte solution under solar simulated light of 1 sun $(0.1 \mathrm{~W}$ $\mathrm{cm}^{-2}$ ). This self-driven PEC was found to produce hydrogen gas at the rate of $12.42 \mathrm{~L} \mathrm{~m}^{-2} \mathrm{~h}^{-1}$ and a solar to hydrogen efficiency (STHE) of $3.25 \%$ from the collected $\mathrm{H}_{2}$ gas in $2.5 \mathrm{M} \mathrm{KOH}$ solution. No signs of degradation of this single chip PEC were observed during water splitting when the device was run continuously for 6 hours.
\end{abstract}

Keywords: Water-splitting, Triple-Junctions amorphous-Silicon, photovoltaic.

\section{INTRODUCTION}

Photoelectrochemical splitting of water converting solar energy to hydrogen fuel offers an alternative energy solution, which is clean and renewable [1-12]. The cost of converting solar energy to hydrogen can be minimized by the use a self-driven monolithic photoelectrochemical cell (PEC) that would eliminate the costs associated with separate construction and interconnection of solar cells and the water electrolyzer [13]. The concept is to develop a leaf-like water splitting PEC as shown in Figure 1 that would split water into hydrogen and oxygen under sunlight illumination. Such process is promising with the use of semiconductors that generate enough power under sunlight illumination to drive the thermodynamically uphill water splitting reaction. Among the existing solar photovoltaic, silicon based solar cells can satisfy the criteria of such water splitting PECs.

Since the first publication on amorphous silicon (a$\mathrm{Si}$ ) in the late 1960s, a-Si has been considered as a promising material compared to the crystalline silicon based solar cells [14, 15]. Furthermore, a-Si has a better photoresponse in the more energetic visible region of the solar spectrum compared to crystalline silicon which is mostly sensitive in the less energetic longer wavelengths (IR) region [14, 15]. Amorphous silicon (a-Si) has been investigated as an alternative to polycrystalline silicon for the use in solar cells. However, stability issues of a-Si in aqueous electrolytes and its high valence band position with

*Address correspondence to this author at the Department of Chemistry and Biochemistry, Duquesne University, Pittsburgh, PA 15282, USA;

Tel: 412-396-1647; Fax: 412-396-6682; E-mail: khan@duq.edu respect to the oxygen oxidation potential [12] make it unfavorable for direct water splitting under sunlight illumination. These limitations can be surmounted by covering a-Si based photovoltaic with visible light transparent stable thin films. While a-Si based solar cell provides the necessary photovoltage to drive the water splitting reaction under sunlight illumination, the appropriate deposited thin film layer can protect the underlying a-Si and as well as provides the favorable valence band position for water splitting. High band gap oxide based semiconductors are visible light transparent and stable in basic electrolytes. Such oxides can be used as a transparent conductive corrosion resistant (TCCR) layer to protect a-Si based photoelectrode in electrolyte solutions.

Recently, coating with thin films has become accessible with the use of dip coating, spin coating, chemical vapor deposition and electro-deposition techniques [16-19]. The cost effective thin films to be used as TCCR protective layer on a-Si are the transition metal oxides. For example, titanium oxide $\left(\mathrm{TiO}_{2}\right)$ is stable in alkaline medium and absorbs only in the UV region of the solar spectrum. Also, a thin film coating of $\mathrm{Mn}_{2} \mathrm{O}_{3}$ was found to stabilize crystalline $n-\mathrm{Si}$, $\mathrm{n}-\mathrm{TiO}_{2}$ and $\mathrm{n}-\mathrm{GaAs}$ thin films in earlier studies $[18,19]$. Some important studies pioneered in utilizing PECs such as crystalline Si (pin-pin) [20], p/n-GaAs [19], p/nSi [21-23], n/p-GaAs/p-GalnP 2 [24], p/n- $\mathrm{Fe}_{2} \mathrm{O}_{3}$ [25], and triple junction amorphous silicon $[26,27]$ for monolithic photoelectrochemical water splitting without the need of additional power from an external source.

In this work we report a single chip water splitting photoelectrochemical cell (PEC) in which a triple junction amorphous silicon (Tj-a-Si) cell deposited on stainless steel substrate was covered with a thin layer 
of $\mathrm{Mn}$-oxide- $\mathrm{TiO}_{2}$ and submersed in $2.5 \mathrm{M} \mathrm{KOH}$ electrolyte solution. Under solar simulated light of 1 sun the device splits water without the use of any external power source where oxygen evolution occurred on the front Mn-oxide- $\mathrm{TiO}_{2}$ coated Tj-a-Si surface (photoanode) and hydrogen evolved at the stainless steel (cathode) as seen in Figure 1.

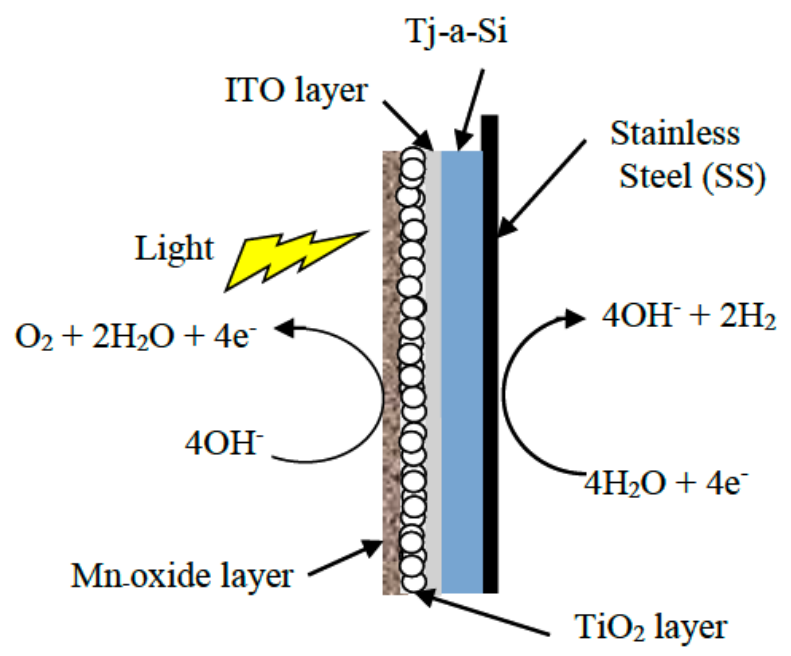

Figure 1: A single chip standalone water splitting photoelectrochemical cell (PEC).

\section{EXPERIMENTAL PROCEDURE}

\subsection{Deposition of a Transparent $\mathrm{TiO}_{2}$ Thin Layer on Tj-a Si Surface}

An advanced method was used to deposit a uniform and durable thin film of $\mathrm{TiO}_{2}$ on Tj-a-Si surface. In this method an ultrafine colloidal solution of $\mathrm{TiO}_{2}$ (Degussa $p$ 25) instead of the suspension was utilized. The colloidal solution consisted of $80 \mathrm{mg}$ of $\mathrm{TiO}_{2}$ powder in
$10 \mathrm{~mL}$ ethanol, in presence of $10 \mu \mathrm{L}$ of a structure directing agent such as acetylacetone [28]. A binder Triton X100 (5 micro liters in $10 \mathrm{~mL}$ ethanol) was added to the suspension to generate uniform films. The mixture was first homogenized in a high-speed centrifuge (Avanti J-20XP) at 3,000 rpm for $15 \mathrm{~min}$ producing a clear colloidal solution at the top and a thick white precipitate at the bottom. A single drop from the top of the ultrafine colloidal solution of $\mathrm{TiO}_{2}$ was spread on the surface of $\mathrm{Tj}-\mathrm{a}-\mathrm{Si}$ with an area of 0.80 $\mathrm{cm}^{2}$; spin coated for $1 \mathrm{~min}$, the procedure was repeated 10 times and then dried at room temperature. The resulting films were sintered at $200^{\circ} \mathrm{C}$ for 1 hour to obtain a uniform solvent free $\mathrm{TiO}_{2}$ thin film on $\mathrm{Tj}$-a-Si surface.

\subsection{Deposition of Manganese Oxide Thin Layer on $\mathrm{TiO}_{2}$ Covered Tj-a Si Cell}

The bath for the deposition of manganese oxide thin layer consisted of aqueous solutions of $0.03 \mathrm{M} \mathrm{MnCl}_{2}$ and $1.4 \mathrm{M} \mathrm{NH}_{4} \mathrm{OH}$, having a total volume of $50 \mathrm{~mL}$. A $0.25 \mathrm{M} \mathrm{NH}_{4} \mathrm{Cl}$ solution was added to this mixture to lower the $\mathrm{pH}$ so that slow precipitation of $\mathrm{Mn}(\mathrm{OH})_{2}$ occurs. This solution was stirred continuously at room temperature. The $\mathrm{TiO}_{2}$ thin film covered Tj-a-Si sample was immersed in the deposition bath for 15 minutes to allow deposition of $\mathrm{Mn}(\mathrm{OH})_{2}$ on its surface. The sample was then rinsed with double deionized water and dried at room temperature. The dried $\mathrm{Mn}(\mathrm{OH})_{2}$ covered $\mathrm{TiO}_{2}-$ $\mathrm{Tj}-\mathrm{a}-\mathrm{Si}$ sample was transferred to a glass funnel followed by evacuation to $2 \times 10^{-5}$ torr. The sample in the evacuated glass funnel was heated at $220{ }^{\circ} \mathrm{C}$ for 15 min. Curing $\mathrm{Mn}(\mathrm{OH})_{2}$ under vacuum results in the loss

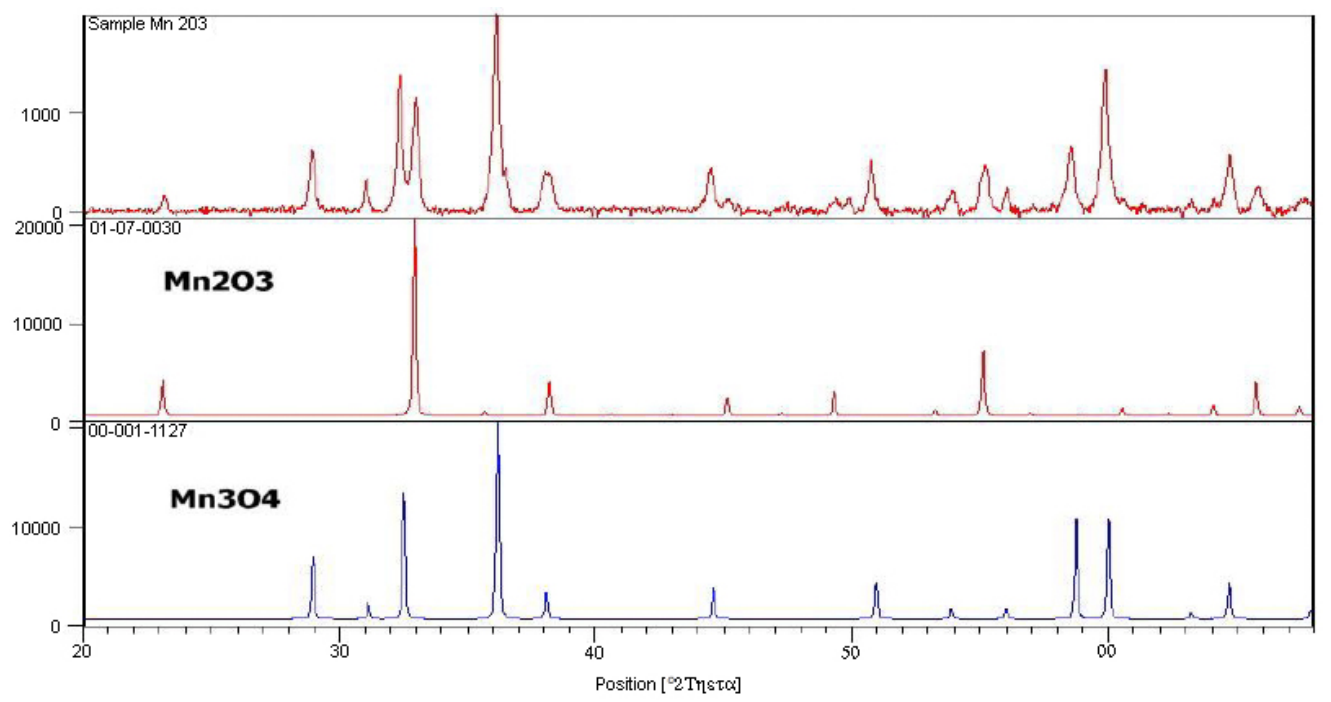

Figure 2: XRD powder patterns for Mn-oxide deposited by drying the $\mathrm{Mn}(\mathrm{OH})_{2}$ in vacuum at $220{ }^{\circ} \mathrm{C}$ (top plot). Patterns for $\mathrm{Mn}_{2} \mathrm{O}_{3}$ and $\mathrm{Mn}_{3} \mathrm{O}_{4}$ are observed, see jcpds card 01-071-0636 and jcpds card 00-001-1127, respectively. 
of water and hydrogen, thereby leaving a thin film of $\mathrm{Mn}_{2} \mathrm{O}_{3}$. The deposition process of $\mathrm{Mn}_{2} \mathrm{O}_{3}$ can be described by chemical reactions [18, 19],

$\mathrm{MnCl}_{2}(\mathrm{aq})+2 \mathrm{NH}_{4} \mathrm{OH}(\mathrm{aq}) \rightarrow \mathrm{Mn}(\mathrm{OH})_{2}(\mathrm{~s})+2 \mathrm{NH}_{4} \mathrm{Cl}(\mathrm{aq})(1)$

During heating at $220^{\circ} \mathrm{C}$ under vacuum of $2 \times 10^{-5}$ torr:

$2 \mathrm{Mn}(\mathrm{OH})_{2}(\mathrm{~s}) \rightarrow \mathrm{Mn}_{2} \mathrm{O}_{3}(\mathrm{~s})+\mathrm{H}_{2}(\mathrm{~g})+\mathrm{H}_{2} \mathrm{O}(\mathrm{g})$

Formation of $\mathrm{Mn}_{2} \mathrm{O}_{3}$ was confirmed earlier by X-ray photoelectron spectroscopy (XPS) [19]. However, the $\mathrm{X}$-ray diffraction (XRD) patterns of the deposited and vacuum cured $\mathrm{Mn}$-oxide thin film in this study shows the presence of $\mathrm{Mn}_{2} \mathrm{O}_{3}$ and $\mathrm{Mn}_{3} \mathrm{O}_{4}$ crystalline phases as seen in Figure 2. This is because drying $\mathrm{Mn}(\mathrm{OH})_{2}$ at $220{ }^{\circ} \mathrm{C}$ in vacuum can also form $\mathrm{Mn}_{3} \mathrm{O}_{4}$ according the reaction,

$3 \mathrm{Mn}(\mathrm{OH})_{2}(\mathrm{~s}) \rightarrow \mathrm{Mn}_{3} \mathrm{O}_{4}(\mathrm{~s})+\mathrm{H}_{2}(\mathrm{~g})+2 \mathrm{H}_{2} \mathrm{O}(\mathrm{g})$

\subsection{Hydrogen Gas Collection at Pt Cathode in Mn- oxide- $\mathrm{TiO}_{2}$ Coated Tj-a-Si /Pt PEC}

Schematic diagram of this single chip Mn-oxide$\mathrm{TiO}_{2}$ coated Tj-a-Si/SS PEC as shown in Figure 1 was modified by connecting a platinum wire (cathode) to the back stainless steel (SS) surface to facilitate $\mathrm{H}_{2}$ gas collection. Oxygen evolution occurred on the front $\mathrm{Mn}$ oxide- $\mathrm{TiO}_{2}$ coated $\mathrm{Tj}-\mathrm{a}-\mathrm{Si}$ surface (photoanode). Hydrogen gas was collected by displacing the electrolyte solution inside a graduated test tube inverted over the platinum wire (cathode). The collected $\mathrm{H}_{2}$ gas was identified by performing gas chromatographic (GC) analysis using an SRI Model 30 TCD gas chromatograph. The measured volume ratio of $\mathrm{H}_{2}$ and $\mathrm{O}_{2}$ collected during water splitting was found to be $2: 1$ as expected. The Mn-oxide- $\mathrm{TiO}_{2}$ coated Tj-a$\mathrm{Si}$ - solar cell was placed at a distance of 7 inches from the solar simulator (Oriel, Model 51192) with global AM 1.5 filters having light intensity of $0.1 \mathrm{~W} \mathrm{~cm}^{-2}$ (1 sun). The intensity of light was measured by a silicon detector, model 10DP/SB (UDT Sensors Inc.). The bias needed for water splitting reaction was provided by the underlying Tj-a-Si solar cell under the same illumination conditions.

\section{RESULTS AND DISCUSSION}

\subsection{Volumes of $\mathrm{H}_{2}$ Gas Collected During Water Splitting}

The volume of hydrogen collected using Mn-oxide$\mathrm{TiO}_{2}$ covered Tj-a-Si electrode (surface area $0.80 \mathrm{~cm}^{2}$ ) as a function of time of exposure under solar simulated light is given in Figure 3. From the slope $\left(0.0207 \mathrm{~mL} \mathrm{H}_{2}\right.$ $\mathrm{cm}^{-2} \mathrm{~min}^{-1}$ ) of the fitted straight line of the plot (Figure 3 inset), the rate of the volume of $\mathrm{H}_{2}$ gas evolution per unit area of cathode surface was obtained. The steady state $\mathrm{H}_{2}$ generation rate was found to be $12.4 \mathrm{~L} \mathrm{~m}^{-2} \mathrm{~h}^{-1}$. The moles of $\mathrm{H}_{2}$ produced per unit area of electrode surface per second, $\mathrm{n}_{\mathrm{H} 2}=1.37 \times 10^{-8} \mathrm{~mol} \mathrm{~cm}^{-2} \mathrm{sec}^{-1}$, were calculated using the ideal gas law as,

$\mathrm{n}_{\mathrm{H} 2}=\left[\left(\mathrm{P}_{\mathrm{atm}}-\mathrm{P}_{\text {water vap }}\right) \times \mathrm{v}_{\mathrm{H} 2} / \mathrm{RT}\right]$

where $\mathrm{V}_{\mathrm{H} 2}$ is the volume of $\mathrm{H}_{2}$ gas collected by displacement of electrolyte solution per unit area of electrode surface per unit time, assumed hydrogen to behave as an ideal gas at atmospheric pressure, and the vapor pressure of water in the electrolyte solution to be equal to that of pure water, $P_{\text {water vap }}=0.03126 \mathrm{~atm}$ (23.76 $\mathrm{mm} \mathrm{Hg}$ ), at room temperature. Also, no signs of degradation of $\mathrm{Mn}$-oxide- $\mathrm{TiO}_{2}$ coated $\mathrm{Tj}$-a-Si were observed when this water splitting PEC was run continuously for 6 hours in $2.5 \mathrm{M} \mathrm{KOH}$ (See Figure 3).

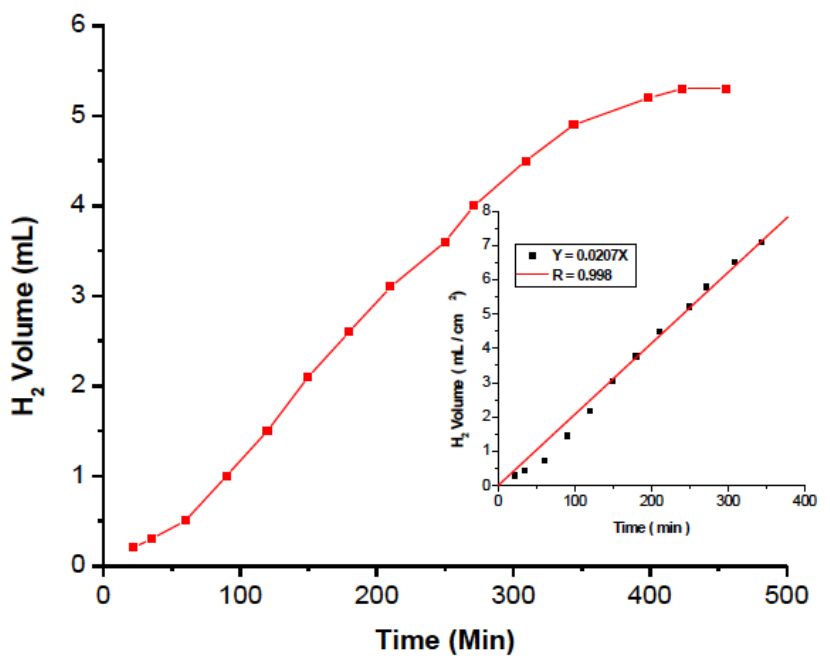

Figure 3: Volume of Hydrogen gas $(\mathrm{mL})$ collected versus time (min). In the inset a fitting line was drawn for the linear part of the plot of volume of $\mathrm{H}_{2}$ gas per photo-electrode area $\left.(\mathrm{mL} \mathrm{cm})^{-2}\right)$ versus time.

\subsection{Solar to Hydrogen Efficiency, STHE (\%)}

The percentage of solar to hydrogen efficiency, STHE (\%), was calculated from the photocurrent density, $j_{p}$ obtained from the number of moles of hydrogen, $\mathrm{n}_{\mathrm{H} 2}$, collected using Faraday's equation and was found to be $2.64 \mathrm{~mA} \mathrm{~cm}^{-2}$. The percentage of solar to hydrogen efficiency STHE (\%) for $\mathrm{H}_{2}$ generation was obtained from the following expression [24-27]:

$\operatorname{STHE}(\%)=\left[\left(\mathrm{j}_{\mathrm{p}} \times \mathrm{E}_{\text {rev }}^{\circ}\right) / \mathrm{P}_{\text {light }}\right] \times 100$

Using the standard reversible potential, $\mathrm{E}_{\mathrm{rev}}^{\circ}=1.23$ $\checkmark$ for the overall water splitting reaction and the light 


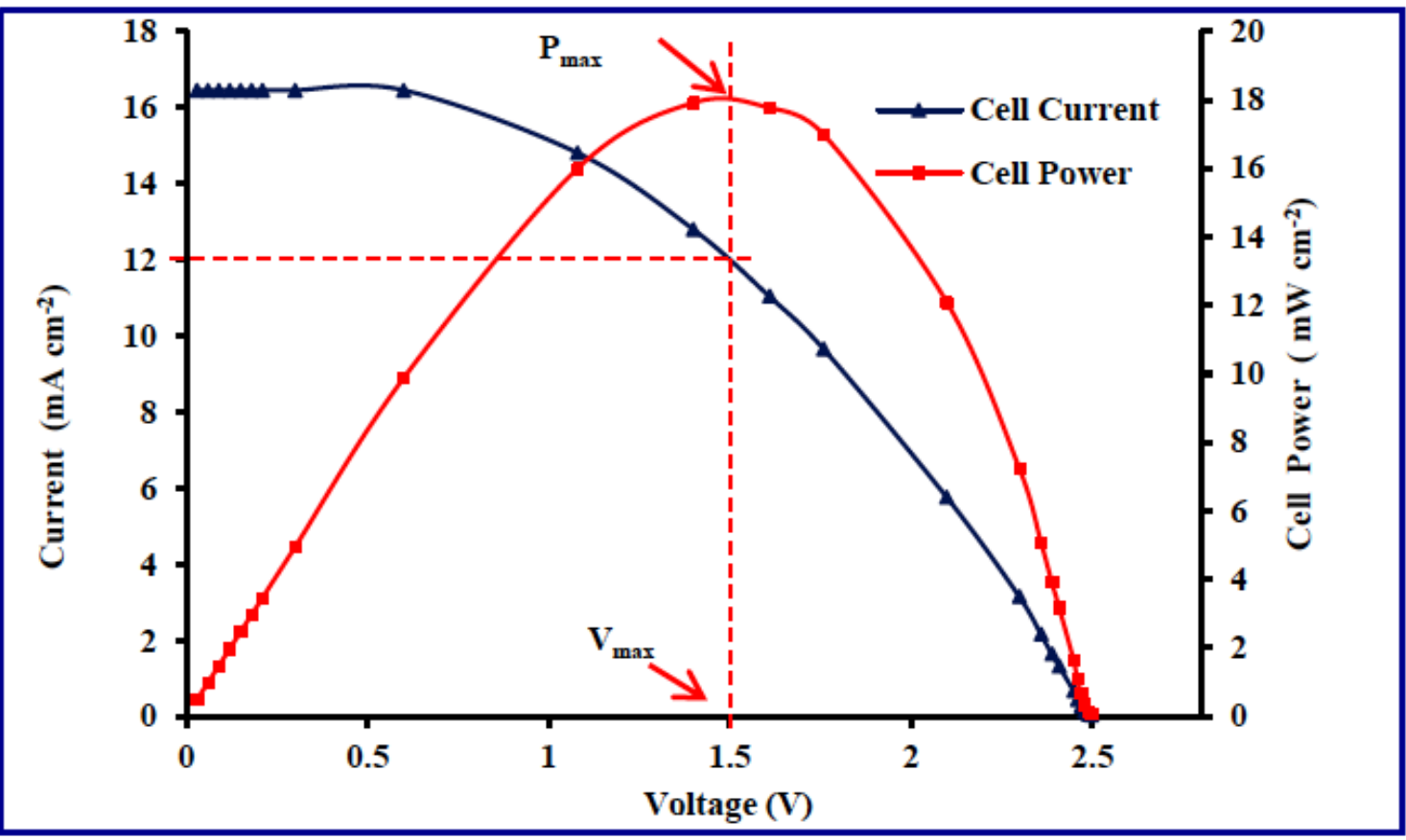

Figure 4: Plots of photocurrent density, $\mathrm{J}_{\mathrm{p}}$, and cell power density versus photovoltage for the unmodified Tj-a-Si solar cell with a surface area of $0.80 \mathrm{~cm}^{2}$ to determine the maximum photovoltage $\left(\mathrm{V}_{\text {max }}\right)$ at a maximum power under solar simulated light of 1 $\operatorname{sun}\left(0.1 \mathrm{~W} \mathrm{~cm}^{-2}\right)$.

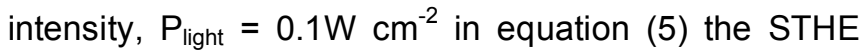
(\%) of $3.25 \%$ was obtained. This is in agreement with STHE (\%) calculated directly from the number of moles of $\mathrm{H}_{2}$ collected, $\mathrm{n}_{\mathrm{H} 2}$ using the equation [29],

$\operatorname{STHE}(\%)=\left[\left(-\Delta \mathrm{G}^{\circ} \times \mathrm{n}_{\mathrm{H} 2}\right) / \mathrm{P}_{\text {light }}\right] \times 100$

with $\Delta G^{\circ}=-237.2 \mathrm{~kJ} \mathrm{~mole}^{-1}$ for the free energy of formation of $\mathrm{H}_{2} \mathrm{O}(\mathrm{l})$ from $\mathrm{H}_{2}(\mathrm{~g})$ and $\mathrm{O}_{2}(\mathrm{~g})$ under standard state condition, $\mathrm{n}_{\mathrm{H} 2}=1.37 \times 10^{-8} \mathrm{~mol}_{\mathrm{H} 2} \mathrm{~cm}^{-2}$ $\sec ^{-1}$ and $P_{\text {light }}=0.1 \mathrm{~W} \mathrm{~cm}^{-2}$.

This observed low solar to hydrogen efficiency of $3.25 \%$ was attributed to low maximum photovoltage of 1.5 volt supplied by the Tj-a-Si solar cell for water splitting as shown in its I-V plot in Figure 4. The Mnoxide- $\mathrm{TiO}_{2}$ coating also decreased the photovoltage and photocurrent by preventing some of the incident light from reaching the underlying $\mathrm{Tj}-\mathrm{a}-\mathrm{Si}$ solar cell.

It should be noted that the Tj-a-Si solar cell that we used in this study could generate maximum photovoltage of $1.5 \mathrm{~V}$ only. Though this photovoltage is just enough to split water, it is not sufficient to overcome the overpotential developed due to $\mathrm{H}_{2}$ and $\mathrm{O}_{2}$ gas evolution on electrode surfaces during water splitting reaction. High maximum photovoltage (> 2.0 $\mathrm{V})$ and high photocurrent generating solar cells are needed to be used in a monolithic PEC for the selfdriven photosplitting of water with high solar to hydrogen efficiency ( $\geq 10.0 \%$ [13]). Furthermore, the thin layer of Mn-oxide on $\mathrm{TiO}_{2}$ covered $\mathrm{Tj}$-a-Si acted as a protective layer; however, it was not an efficient electrocatalyst for the oxygen evolution reaction (OER). The protective layer should possess high electrocatalytic activity towards OER. Though rare metal oxide such as $\mathrm{RuO}_{2}$ acts as one of the best electrocatalyst for OER, some other earth abundant oxides such as Co-oxide [30, 31], Ni-Co-mixed oxide $[32,33]$ and other transition metal oxides and mixed oxides [34, 35] can be used as efficient catalysts for OER and as well as optically transparent protective layer to enhance the efficiency of water splitting reaction.

\subsection{Scanning Electron Microscopic (SEM) Pictures of $\mathrm{TiO}_{2}$ Covered and $\mathrm{Mn}$-oxide-TiO ${ }_{2}$ Covered Tj-a-Si}

The Scanning electron microscopic (SEM) pictures of $\mathrm{TiO}_{2}$ covered $\mathrm{Tj}$-a-Si and $\mathrm{Mn}$-oxide- $\mathrm{TiO}_{2}$ covered $\mathrm{Tj}$ a-Si are given in Figures 5. It is observed that the $\mathrm{TiO}_{2}$ layer was not thick enough to protect the underlying $\mathrm{Tj}$ a-Si. Noticeably, the Mn-oxide- $\mathrm{TiO}_{2}$ appears robust and thick enough to protect $\mathrm{Tj}$-a-Si cell. However, at some darker spots the layer is porous and is not uniform where pinholes were generated after continuous water splitting for six hours in $2.5 \mathrm{M} \mathrm{KOH}$ solution. Hence, it is essential to deposit robust non-porous uniform thin films to avoid generation of pinholes during water splitting reaction. 

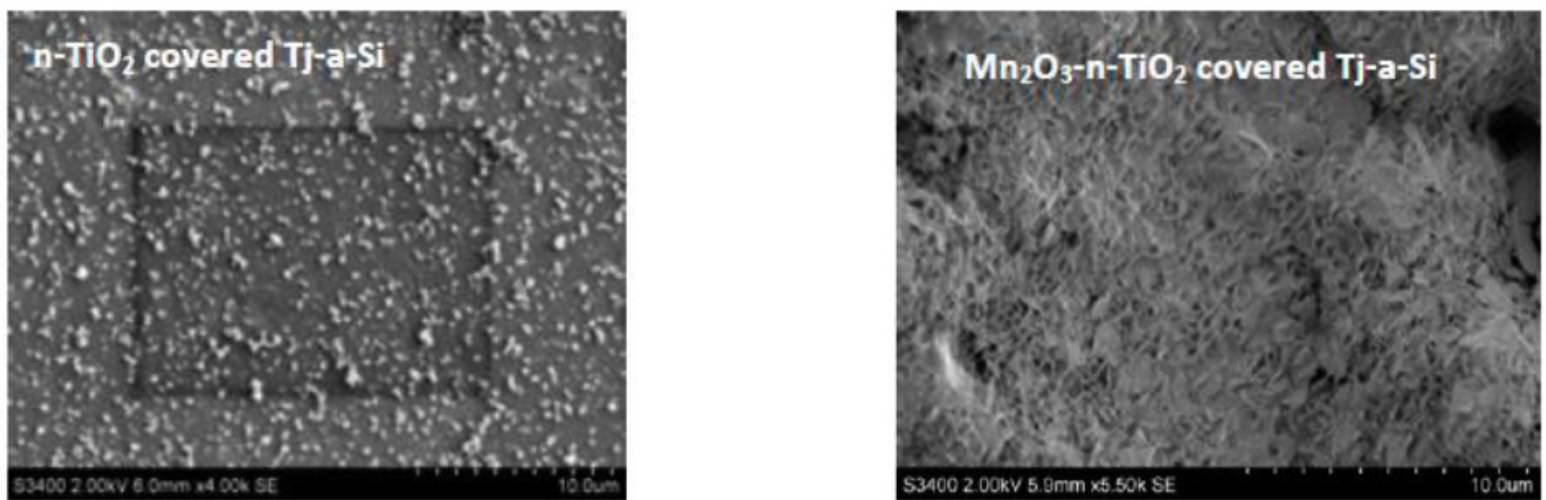

Figure 5: Scanning Electron Microscopic (SEM) pictures of $\mathrm{TiO}_{2}$ covered Tj-a-Si and Mn-oxide-TiO 2 covered $\mathrm{Tj}-\mathrm{a}-\mathrm{Si}$.

\section{CONCLUSION}

In this study Mn-oxide- $\mathrm{TiO}_{2}$ coated $\mathrm{Tj}$-a-Si was successfully used for monolithic self-driven water splitting to $\mathrm{H}_{2}$ and $\mathrm{O}_{2}$ having solar to hydrogen efficiency of $3.25 \%$ under solar simulated light illumination of 1 sun. Higher solar to hydrogen efficiency could be achieved if higher maximum photovoltage generating Tj-a-Si cell were used and protected with a better corrosion resistant electrocatalyst layer. The coating on $\mathrm{Tj}$-a-Si by a corrosion resistant transparent layer of $\mathrm{Mn}$-oxide- $\mathrm{TiO}_{2}$ was essential to enhance its stability during water splitting reaction which is more than ten-fold increase in stability compared to an earlier study [27] in which Tj-a$\mathrm{Si}$ started to degrade sharply after half an hour in $0.1 \mathrm{M}$ $\mathrm{KOH}$ solution. Long-term stability can be achieved if a pinhole free transparent corrosion resistant non-porous layer could be deposited on Tj-a-Si cells. Hence, future studies should focus on depositing a better adherent visible light transparent thin layer on the surface of $\mathrm{Tj}$ a-Si for its stability for long operating time.

\section{ACKNOWLEDEMENT}

We gratefully acknowledge the financial support of US Air force to Duquesne University via a subcontract from the University of Toledo.

\section{REFERENCES}

[1] Walter MG, Warren EL, McKone JR, Boettcher SW, Mi Q, Santori EA, Lewis NS. Solar water splitting cells. Chem Rev 2010; 10: 6446-73.

http://dx.doi.org/10.1021/cr1002326

[2] Maeda K, Photocatalytic water splitting using semiconductor particles: History and recent Developments. J Photochem Photobiol C: Photochem Rev 2011; 12: 237-68. http://dx.doi.org/10.1016/j.jphotochemrev.2011.07.001

[3] Meng F, Li J, Cushing SK, Zhi M, Wu NQ. Solar hydrogen generation by nanoscale $\mathrm{p}$-n junction of p-type molybdenum disulfide/n-type nitrogen-doped reduced graphene oxide. J Am Chem Soc 2013; 135: 10286-89.

http://dx.doi.org/10.1021/ja404851s
Saito R, Misekia K, Sayama K. Highly efficient photoelectrochemical water splitting using a thin film photoanode of $B \mathrm{BVO}_{4} / \mathrm{SnO}_{2} / \mathrm{WO}_{3}$ multi-composite in a carbonate electrolyte. Chem Commun 2012; 48: 3833-35. http://dx.doi.org/10.1039/c2cc30713h

[5] Khan SUM, Al-Shahry M, Ingler Jr W. Efficient photochemical water-splitting by chemically modified $n-\mathrm{TiO}_{2}$. Science 2002; 297: 2243-45.

http://dx.doi.org/10.1126/science. 1075035

[6] Mohaputra SK, Misra M, Mohajan VK, Raja KS. Design of a highly efficient photoelectrolytic cell for hydrogen generation by water splitting: Application of $\mathrm{TiO}_{2-x} \mathrm{C}_{x}$ nanotubes as a photoanode and $\mathrm{Pt} / \mathrm{TiO}_{2}$ nanotubes as a cathode. J Phys Chem C 2007; 111: 8677-85. http://dx.doi.org/10.1021/jp071906v

[7] Shankar K, Paulose M, Mor GK, Varghese OK, Grimes CA. A study on the spectral photoresponse and photoelectrochemical properties of flame-annealed titania nanotubearrays. J Phys D: Appl Phys 2005; 38: 3543-50. http://dx.doi.org/10.1088/0022-3727/38/18/033

[8] Park JH, Kim S, Bard AJ. Novel carbon-doped $\mathrm{TiO}_{2}$ nanotube arrays with high aspect ratios for efficient solar water splitting. Nano Lett 2006; 6: 24-28.

http://dx.doi.org/10.1021/nl051807y

[9] Frites $M$, Shaban $\mathrm{YA}$, Khan SUM. Iron Oxide $\left(\mathrm{n}-\mathrm{Fe}_{2} \mathrm{O}_{3}\right)$ nanowire films and carbon modified (CM)-n- $-\mathrm{Fe}_{2} \mathrm{O}_{3}$ thin films for hydrogen production by photosplitting of water. International $\mathrm{J}$ Hydrogen Energy 2010; 35: 4944-48. http://dx.doi.org/10.1016/j.jjhydene.2009.08.070

[10] Frites M, Khan SUM. Visible light active hydrogen modified (HM)-n- $\mathrm{TiO}_{2}$ thin films for photoelectrochemical splitting of water. Electrochem Commun 2009; 11: 2257-60.

http://dx.doi.org/10.1016/j.elecom.2009.10.005

[11] Sun KY, Murphy CJ, Reyes-Gil R, Sun Y, Reyes-Garcia EA, Raftery D. Characterization of photoactive centers in NDoped $\ln _{2} \mathrm{O}_{3}$ Visible Photocatalysts for Water Oxidation. J Phys Chem 2009; 113: 12558-70.

[12] Kudo A, Miseki Y. Heterogeneous photocatalyst materials for water splitting. Chem Soc Rev 2009; 38: 253-78. http://dx.doi.org/10.1039/b800489g

[13] Bard AJ, Fox MA. Artificial photosynthesis, Acc Chem Res 1995; 28: 141-45. http://dx.doi.org/10.1021/ar00051a007

[14] Goetzberger A, Hoffmann VU. Photovoltaic solar energy generation. Springer 2005.

[15] Rech B, Wagner H. Potential of amorphous silicon for solar cells. Appl Phys A 1999; 69: 155-67. http://dx.doi.org/10.1007/s003390050986

[16] Karuppuchamy S, Jeong J-M, Amalnerkar DP, Minoura H. Photoinduced hydrophilicity of titanium dioxide thin films 
prepared by cathodic electrodeposition. Vacuum 2006; 80 : 494-98.

http://dx.doi.org/10.1016/j.vacuum.2005.06.005

[17] Natarajan C, Nogami G. Cathodic electrodeposition of nanocrystalline titanium dioxide thin films. J Electrochem Soc 1996; 143: 1547-50

http://dx.doi.org/10.1149/1.1836677

[18] Khan SUM, Akikusa J. Stability and photoresponse of nanocrystalline $\mathrm{n}-\mathrm{TiO}_{2}$ and $\mathrm{n}$ - $\mathrm{TiO}_{2} / \mathrm{Mn}_{2} \mathrm{O}_{3}$ thin film electrodes during water splitting reactions. J Electrochem Soc 1998; 45: 89-93.

http://dx.doi.org/10.1149/1.1838217

[19] Kainthla C, Zelenay B, Bockris J O'M. Significant efficiency increase in self-driven photoelectrochemical cell for water photoelectrolysis. J Electrochem Soc 1987; 134: 841-45. http://dx.doi.org/10.1149/1.2100583

[20] Lin GH, Kapur M, Kainthla RC, Bockris JO’M. One step method to produce hydrogen by a triple stack amorphous silicon solar cell. Appl Phys Lett 1989; 55: 386-88. http://dx.doi.org/10.1063/1.101879

[21] Rocheleau R, Miller E. High efficiency photoelectrochemical hydrogen production using multijuction amorphous silicon photoelectrodes. Energy Fuels 1998; 12: 3-10. http://dx.doi.org/10.1021/ef9701347

[22] Morisaki $\mathrm{H}$, Watanabe $\mathrm{T}$, Iwase $\mathrm{M}$, Yazawa $\mathrm{K}$. Photoelectrolysis of water with $\mathrm{TiO}_{2}$-covered solar-cell electrodes. Appl Phys Lett 1976; 29: 338-40. http://dx.doi.org/10.1063/1.89088

[23] Kelly NA, Gibson TL. Design and characterization of a robust photoelectrochemical device to generate hydrogen using solar water splitting. Int J Hydrogen Energy 2006; 31: 165873.

http://dx.doi.org/10.1016/j.ijhydene.2005.12.014

[24] Khaselev O, Turner JA. A monolithic photovoltaicphotoelectrochemical device for hydrogen production via water splitting. Science 1998; 280: 425-27. http://dx.doi.org/10.1126/science.280.5362.425

[25] Ingler Jr WB, Khan SUM. A self-driven $\mathrm{p} / \mathrm{n}-\mathrm{Fe}_{2} \mathrm{O}_{3}$ tandem photoelectrochemical cell for water splitting. Electrochem Sol Stat Lett 2006; 9: G144-G148. http://dx.doi.org/10.1149/1.2176082

[26] Frites M, Ingler Jr W, Khan SUM. Photoelectrolysis of water in Tj-a-Si solar cell biased $\mathrm{CM}-\mathrm{n}-\mathrm{TiO}_{2}|| \mathrm{Pt}$ and in monolithic self-driven $\mathrm{n}-\mathrm{TiO}_{2}-\mathrm{Mn}_{2} \mathrm{O}_{3}$ coated $\mathrm{Tj}-\mathrm{a}-\mathrm{Si}|| \mathrm{Pt}$ photoelectrochemical cell. ECS Trans 2010; 25: 73-82.

http://dx.doi.org/10.1149/1.3416203

[27] Reece SY, Hamel JA, Sung K, Jarvi TD, Esswein JA, Pijpers JJH, Nocera DG. Wirless solar water splitting using silicon based semiconductors and earth abundant Catalysts. Science 2011; 334: 645-48. http://dx.doi.org/10.1126/science.1209816

[28] Neumann B, Bogdanoff P, Tributsch H, Sakthivel S, Kisch H. Electrochemical mass spectroscopic and surface photovoltage studies of catalytic water photooxidation by undoped and carbon-doped titania. J Phys Chem B 2005; 109: $16579-86$

http://dx.doi.org/10.1021/jp051339g

[29] Park H, Vecitis CD, Choi W, Weres O, Hoffmann MR, Solarpowered production of molecular hydrogen from water. $J$ Phys Chem C 2008; 112: 885-89. http://dx.doi.org/10.1021/jp710723p

[30] Ardizzone S, Spinolo G, Trasatti S. The point of zero charge of $\mathrm{Co}_{3} \mathrm{O}_{4}$ prepared by thermal decomposition of basic cobalt carbonate. Electrochem Acta 1995; 40: 2683-86.

http://dx.doi.org/10.1016/0013-4686(95)00238-A

[31] Kanan MW, Nocera DG. In situ formation of an oxygen evolving catalyst in neutral water in containing phosphate and $\mathrm{Co}^{2+}$ ion. Science 2008; 321: 1072-75. http://dx.doi.org/10.1126/science.1162018

[32] Bocca C, Barbucci A, Delucchi M, Cerisola G. Nickel-cobalt oxide-coated electrodes: influence of the preparation technique on oxygen evolution reaction (OER) in an alkaline solution. Int J Hydrogen Energy 1999; 24: 21-26. http://dx.doi.org/10.1016/S0360-3199(98)00012-3

[33] Castro EB, Real SG, Dick LFP. Electrochemical characterization of porous nickel-cobalt oxide electrodes. Int J Hydrogen Energy 2004; 29: 255-61. http://dx.doi.org/10.1016/S0360-3199(03)00133-2

[34] Chemelewski WD, Lee HC, Lin JF, Bard AJ. Amorphous $\mathrm{FeOOH}$ Oxygen Evolution Reaction Catalyst for Photoelectrochemical Water Splitting. J Am Chem Soc 2014; 136: 2843-50. http://dx.doi.org/10.1021/ja411835a

[35] McCrory CCL, Jung S, Peters JC, Jaramillo TF. Benchmarking Heterogeneous Electrocatalysts for Oxygen Evolution Reaction. J Am Chem Soc 2013; 135: 16977-87. http://dx.doi.org/10.1021/ja407115p

\section{DOI: http://dx.doi.org/10.6000/1929-6002.2014.03.01.2}

(c) 2014 Frites et al.; Licensee Lifescience Global.

This is an open access article licensed under the terms of the Creative Commons Attribution Non-Commercial License (http://creativecommons.org/licenses/by-nc/3.0/) which permits unrestricted, non-commercial use, distribution and reproduction in any medium, provided the work is properly cited. 